\title{
AS TRÊS PRESUNÇÕES DE PATERNIDADE NO DIREITO DE FAMÍLIA BRASILEIRO: UMA ANÁLISE CRÍTICA E TÓPICA SOB O PRISMA DO AFETO
}

LUCIANA AGLANTZAKIS. 


\title{
AS TRÊS PRESUNÇÕES DE PATERNIDADE NO DIREITO DE FAMÍLIA BRASILEIRO: UMA ANÁLISE CRÍTICA E TÓPICA SOB O PRISMA DO AFETO.
}

Luciana Aglantzakis ${ }^{1}$

\section{RESUMO}

Existem três presunções de paternidade no ordenamento jurídico brasileiro: a paternidade legal, biológica e socioafetiva. Compreende-se ser preponderante aceitar que nas possíveis e imaginárias situações que envolvam litígios de parentalidade a paternidade socioafetiva deve prevalecer em relação às demais, mesmo em situação de evidente proibição legal expressa no Código Civil. O presente artigo versa sobre uma análise crítica e tópica de possível paternidade entre irmãos que em tese veicula o conflito jurídico entre a paternidade biológica, legal e socioafetiva.

\section{Palavras-chave:}

Paternidade legal. Paternidade socioafetiva. Paternidade biológica. Presunção paternidade e Investigação.

\begin{abstract}
There are three presumptions of paternity in the Brazilian legal system: the legal paternity, biological and socio-affective. It is understood to accept that the role and possible situations involving parenting disputes in the socio-affective father should prevail over the others, even in situations of clear express statutory prohibition in the Civil Code. This work focuses on a topical and critical analysis of possible paternity among siblings which supposedly conveys the legal dispute between the biological paternity, legal and socio-affective.
\end{abstract}

\section{Keywords:}

Paternity legal. Paternity socio-affective. Biological paternity. Paternity presumption and Investigation.

Esse artigo veicula um debate crítico sobre o afeto nos processos de investigação e negatória de paternidade que são

\footnotetext{
'Juíza Estadual. Tribunal de Justiça do Estado do Tocantins. Pós-Graduada em Direito Constitucional Faculdade Atual e OAB/RR . Pós-Graduada em Jurisdição Faculdade Upis e Escola Magistratura do DF
} 
instruídos nas Varas de Família no ordenamento jurídico brasileiro.

Inúmeras situações podem ocorrer no processamento das lides que levem ao Juiz decidir situações de conflito no Direito de Família em relação ao tema " presunção e investigação de paternidade".

Como decidiria um magistrado se por acaso se deparasse com uma lide de um pai que deseja reconhecer a paternidade de uma criança com a paternidade já reconhecida em um registro por erro devido ao fato do seu filho ter sido trocado na maternidade?

Imaginemos, ainda, um pedido de decreto de anulação de um pai registral que tenha se declarado espontaneamente como pai biológico há mais de uma década e compõe a causa de pedir da ação o detalhe de que a criança declarada filha no registro de nascimento, na verdade, era seu irmão, fruto de um estupro do avô paterno em face da mãe da criança, sua esposa, que gerou o direito de que a criança obtenha o registro civil em face da presunção legal de paternidade.

Entretanto, esta segunda relação jurídica é um exemplo de que a teoria não consegue imaginar todas as situações possíveis e o Juiz deve pensar em aplicar o direito à espécie com Justiça, mesmo em șituações tipicamente absurdas, prestigiando a opção jurídica da presunção socioafetiva da paternidade.

Cabe registrar que existem três critérios para determinar a filiação no Direito Civil Brasileiro : o legal ou jurídico, o biológico e o socioafetivo.

Segundo Deocleciano Torrieri Guimarães, na sua obra Dicionário Técnico Jurídico presunção é a "conjetura, juízo antecipado e provisório; aquilo que se presume"( Editora Rideel, $2005,7^{a}$ edição, São Paulo-SP, página 451). O significado jurídico de paternidade nessa mesma obra às fls. 432 significa "qualidade, situação, de quem é pai".

A paternidade biológica prestigia a verdade biológica em que prepondera na causa de pedir a concepção e o exame do DNA.

A paternidade legal é a prevista no artigo 1597 do Código Civil. Significa uma presunção legal segundo o qual se presumem concebidos na constância do casamento os filhos nascidos cento e oitenta dias, pelo menos, depois de estabelecida à convivência conjugal; os nascidos nos trezentos dias subseqüentes à dissolução 
da sociedade conjugal, por morte, separação judicial, nulidade e anulação de casamento, havidos por fecundação artificial homóloga, mesmo que falecido o marido, havidos, por inseminação artificial heteróloga, desde que tenha prévia autorização do marido e havidos a qualquer tempo, quando se tratar de embriões excedentários, decorrentes de inseminação artificial homóloga, deduzindo-se pela presunção da paternidade legal que é o pai o marido da mãe da criança, o famoso brocardo "pater est", em que prevalece a paternidade fictícia sobre a verdade biológica.

A paternidade socioafetiva é a paternidade da verdade social, do vínculo afetivo em que há a certeza de uma posse de estado de filho, independentemente de verdade biológica ou fictícia.

Na hipótese de negatória de paternidade cuja causa de pedir envolva verdade biológica que transpareça paternidade entre irmãos entendo que o autor tem a faculdade de provar a subsistência dos critérios biológico e legal, mas também tem que provar que não é pai socioafetivo, pois a paternidade socioafetiva prepondera em face da paternidade legal e biológica, questão jurídica que merece uma consideração excepcional do julgador.

Conforme a doutrina e a jurisprudência dominante que prestigia a paternidade socioafetiva uma solução adequada seria de vislumbrar se há relacionamento afetivo entre o filho registral e pai registral, no sentido de que a solução da lide encontra fundamento no reconhecimento ou não de uma verdade social que transparece evidente paternidade socioafetiva.

Cabe frisar que é pertinente a decisão da ministra Fátima Nancy Andrighi, no REsp 1.067.438-RS, publicada no informativo 385 do Superior Tribunal de Justiça, em que a ministra julgou extinto o processo sem resolução do mérito, no caso de ação negatória de paternidade por dúvida, desconfiança do vínculo biológico, em detrimento do menor, pois na sua convicção jurídica não há vício de consentimento no caso de dúvida.

Entendo que a proposição de uma ação negatória de paternidade com o objetivo de desconstituir o registro de nascimento em que há relevado envolvimento socioafetivo é exemplo de abuso de direito, ato ilícito, conhecido por "venire contra factum proprium" no Direito de Família.

Nelson Rosenvald e Cristiano Chaves de Farias, na sua obra 
Direito das Famílias, Editora Lúmen Iuris, ano de 2008, expressa que a aplicação do "venire factum proprium" é resultado da violação do principio da confiança em que há comportamento contraditório da Parte que dá causa a paternidade socioafetiva e depois com clara violação ao principio da lealdade e solidariedade procura desconstituir o vínculo afetivo que construiu na outra parte.

A paternidade biológica é importante, entretanto, de maior relevo é a paternidade interpretada com a qualificadora da função social, que no Direito da Família é o afeto, e diante da teoria da aparência a paternidade socioafetiva é qualificada pelo amor que merece prevalecer em face da verdade biológica.

O registro em si com o nome de alguém como pai é um detalhe obsoleto, pois em nada modifica a realidade da vida. Trata-se de um símbolo, um sinal exigido para que alguém tenha um nome na sociedade, um registro que não será verdadeiro se não for realmente funcionalizado pelo afeto.

De nada adianta ter um pai apenas no papel. E por que motivo os pais registrais tentam negar em Juízo a validade do registro de nascimento se na maioria das vezes a paternidade da vida real demonstra uma efetiva paternidade socioafetiva devido ao amor que șe constrói dia a dia entre pai e filho.

É premente frisar que o simples fato de um desentendimento futuro não é suficiente para apagar o afeto inicial, pois é regra e princípio basilar do Direito de Família que a paternidade socioafetiva somente pode ser invocada para determinar o estado de filiação e formação do vínculo e jamais para sua negativa.

A personalidade do filho formada pela paternidade socioafetiva não pode ser prejudicada em razão de desentendimentos familiares por demais membros da família e, por estes motivos considero juridicamente possível que um propenso pai registral qualificado pela presunção legal seja em uma lide irmão biológico do filho registrado e prevaleça o registro mesmo que este esteja sendo questionado pela verdade biológica, por prevalecer na situação o "melhor interesse da criança e adolescente" e a paternidade socioafetiva, a paternidade social.

Uma solução científica e jurídica em caso de paternidade registral que contenha impedimento civil no Código Civil deve ser adotada com observância dos artigos $3^{\circ}$ e 70 do ECA, e dos artigos 
1626 e 1593 do Código Civil, e o julgamento em tese pode ser pela procedência da paternidade socioafetiva, que gerou o efeito de desligar o(a) adolescente de vínculo familiar ilícito, sendo em tese juridicamente possível, por exemplo, adoção à brasileira de irmão versus irmão, devendo o registro permanecer válido para todos os fins de Direito, com a ressalva do artigo 1626 do Código Civil, para fins de impedimento matrimonial, se ficar provado nos autos que há exame de DNA atestando que a paternidade biológica da parte autora é realmente do avô paterno registral.

Segundo Jacques Lacan, na sua obra Nomes-do-pai o registro é um símbolo e assim se manifesta:

Trata-se justamente dos pontos em que o símbolo constitui a realidade humana, em que ele cria essa dimensão humana sobre a qual Freud insiste a toda hora quando diz que o neurótico obsessivo vive sempre no registro do que comporta o máximo dos elementos de incerteza: a duração da vida, a paternidade, etc. $\underline{\mathbf{E}}$ constituído, e construído primitivamente, por certas relações simbólicas que podem em seguida encontrar sua confirmação na realidade. O pai é de fato 0 genitor. Mas, antes que o saibamos de fonte segura, 0 nome do pai cria a função do pai (Editora Zahar, Rio de Janeiro, página 47).

O essencial para a formação de uma pessoa, para torná-lo um sujeito capaz socialmente é que "alguém ocupe, em seu imaginário, o lugar simbólico de pai e mãe" mesmo não estabelecendo com eles um vínculo biológico, segundo entendimento de Rodrigo Cunha Pereira, apud Nelson Rosenvald e Cristiano Chaves, na obra dos referidos autores mencionados nesse artigo.

Conforme bem definido por Maria Berenice Dias, na sua obra Manual de Direito das Famílias, $3^{\circ}$ edição, páginas 60/61:

(...) o afeto não é fruto da biologia. Os laços de afeto e de solidariedade derivam da convivência familiar, não do sangue. Assim, a posse de estado de filho nada mais é do que o reconhecimento jurídico do afeto; com o claro objetivo de garantir a felicidade, como um direito a ser alcançado"(apud Paulo Luiz Netto Lobo, Código Civil Comentado, 56).

O Superior Tribunal de Justiça, em recente julgamento, 
noticiado no site de notícias www.stj.jus.br do dia 23.3.2010, trouxe a lume informações de decisão da $3^{\circ}$ Turma do STJ, da lavra do ministro relator Massami Oxida que considerou ser possível que um casal que tenha a guarda provisória de uma criança tenha prioridade na lista dos interessados para adoção; fundamentando sua decisão no afeto. Vejamos trechos da notícia veiculada no site:

Ao relatar o recurso especial do primeiro casal adotante, o ministro Massami Uyeda considerou a existência de vínculo de afetividade entre a criança e o casal com que viveu diariamente durante seus primeiros oito meses de vida. Ele ressaltou que a convivência foi autorizada por decisões judiciais, inclusive com laudo psicossocial. O ministro também não concordou com o fundamento adotado pelo tribunal local no sentido de que a criança, por ter menos de um ano de idade, e considerando a formalidade do cadastro, poderia ser afastada do casal. Para Uyeda, os desembargadores não levaram em consideração "o único e imprescindível critério a ser observado, qual seja, a existência de vínculo de afetividade da infante com o casal adotante.

Trago à baila, contribuição da renomada psicanalista Giselle Groeninga, membro do IBDFAM, (Instituto Brasileiro de Direito da Família) onde tive a especial oportunidade de manter um diálogo digital por email, sobre o tema em tese de afeto na presunção de paternidade entre irmãos.

O mistério da parentalidade nos constitui - quem são, o que representam, e como nos desejam (amam, odeiam, acolhem, rejeitam etc.). É certo que tal mistério não se resolve, nunca chegamos á sua essência. Os fantasmas sempre existirão, mas a parentalidade deve encontrar representantes nomeados- pai, mãe, sejam eles um de cada ou vários (estes que não cabem nas linhas a eles destinadas pelas certidões). Há muitos filhos da estrela, lembrando o texto de Fachin, ou da falta de espaço."

Nesse sentido, cabe trazer a excelente transcrição de Maria Alice Zaratin Lotufo, na sua obra Curso Avançado de Direito Civil (2002), que se amolda ao estudo apresentado no presente artigo, em que a presunção da paternidade hodierna passa por uma fase crítica afirmativa, no sentido de que:

Ocorre que a realidade fática e a científica caminham na frente da jurídica e, de outro modo, não poderia ser. No 
entanto, por vezes, esta demora legislativa em refletir aquelas realidades e discipliná-las traz como conseqüência um distanciamento entre as idéias, os conceitos e os objetivos, levando os juristas, através da doutrina, e os tribunais, através da jurisprudência, a procurarem, em suas criações, diminuir essa defasagem (página 191).

\section{CONCLUSÃO:}

Atualmente existem três presunções de paternidade do direito brasileiro, três critérios para determinar a filiação no Direito Civil Brasileiro: o legal ou jurídico, o biológico e socioafetivo.

Conclui-se do presente artigo que se comprende pela atual fase jurisprudencial brasileira e pela Doutrina que prevalece a presunção socioafetiva em face da presunção de paternidade registral e legal, mormente em situações limítrofes que cabe ao magistrado adotar uma norma razoável em face do afeto.

\section{Bibliografia}

BRASIL. Código Civil Brasileiro (2002). 2. ed. São Paulo: Saraiva, 2005.

DIAS, Maria Berenice. Manual dos Direitos das Famílias. $3^{\circ} \mathrm{ed}$. São Paulo: Editora Revista dos Tribunais, 2006.

FARIAS, Cristiano Chaves e ROSENVALD, Nelson. Direito das Famílias, Rio de Janeiro: Editora Lúmen Iuris, 2008.

GUIMARÃES, Deocleciano Torrieiri. Dicionário Técnico Jurídico. São Paulo: Editora Rideel, 2005.

LACAN, Jacques. Nomes-do-pai. Rio de Janeiro: Editora Zahar, 2009.

LOTUFO, Maria Alice Zaratin. Curso Avançado de Direito Civil. Volume 5, coord. Everaldo Cambier. São Paulo: Editora Revista dos Tribunais, 2002. 